\title{
Creating Authentic Reading Materials for EFL Learners In Uzbekistan
}

\author{
AVILOVA KHALIDA NABIJANOVNA ${ }^{\mathbf{1}}$ \\ Uzbekistan State University of World Languages. Email: khalida72@ mail.ru
}

GULYAMOVA MAVLUDA KHAMITOVNA ${ }^{2}$

Uzbekistan State University of World Languages. Email: mavludagulyamova82@ mail.ru

\section{AKBAROVA SHAKHNOZA XIKMATULLAYEVNA ${ }^{3}$}

International Islamic Academy.

\begin{abstract}
Reading skill plays an important role as it is an indispensible tool in majority language classrooms. Selection and development of EFL (English as a Foreign Language) reading materials relevant to local context must be carefully done by the teachers, because every internet resource or course book may not be appropriate in all classrooms. This paper gives an overview about reading material development and the selection of authentic materials for designing reading tasks in the English as a foreign language classroom in Uzbekistan. It also looks for theories which support the efforts in developing culturally and locally appropriate EFL reading materials.
\end{abstract}

Keywords:

authentic materials, authenticity, reading skills, reading strategies, reading genres.

Article Received: 18 October 2020, Revised: 3 November 2020, Accepted: 24 December 2020

\section{Introduction}

After gaining independence in 1991, there has been turning changes in the education system of Uzbekistan. Many documents were approved by the government to enhance teaching foreign languages at all stages of education throughout the country. Much effort is being paid to creating teaching materials that provide $\mathrm{C} 1$ level of Common European Competence in Higher Educational Establishments of Foreign Language Specialties. In accordance with this, several local resources were created for primary and secondary schools and they have been used widely in the field of language teaching in Uzbekistan. (Juraev L \& others, 2005)

Nevertheless, language teachers need to know efficient ways to create, adapt and select appropriate language teaching materials to suit local context. There have been done limited research in material development, however, few researches were done on the theory of text analysis in Uzbekistan: such as M.D.Daniyeva, N.A.Tukhtahkodjaeva, U.R.Yuldoshev .(Daniyeva M.D., Tukhtahkodjaeva N.A., Yuldoshev U.R.,2017).

In the dissertation, M.D. Daniyeva defined the conceptual bases of semantic functional, derivational and text forming features of substantive phrases. Besides that, the text forming features of the English phrases and their place in the process of text coherence, the expressive functions of the English Phrases in communicative-pragmatical content are defined. N.A. Tukhtahkodjaeva's research work studied the representation of English and Uzbek universal and national linguaculturems in literary translation and in translations of linguaculturems verbalized by English and Uzbek stylistic devices, the role of using varied ways of translation such as analogy, equivalent and descriptive, has been proved. U.R. Yuldoshev provided the research on peculiarities of stylistic devices and national-cultural lexical 
units in translation of the Uzbek national anecdotes into the English language. The research work has been clarified that metaphor, metonymy, irony, hyperbole, personification, allusion stylistic devices actively used in the Uzbek national anecdotes and the techniques of translating these stylistic devices into English were worked out. These researchers analyzed authentic materials in both: English and Uzbek languages to some extent, however, they are not directly related to material selection and development.

\section{Defining authentic materials}

Meaning of authentic materials has been defined differently by many researchers. Marrow defines authentic material as a "stretch of real language, produced by a real speaker or writer for a real audience and designed to carry a real message of some sort" (Brown, H. D, 1991). Swaffar says that "an authentic text, oral or written, is one whose primary intent is to communicate meaning" (Rogers L \& Wilkin J, 2017).Tomlinson says "an authentic text is one which is produced in order to communicate rather than to teach. ... The text does not have to be produced by a native speaker and it might be a version of an original which has been simplified to facilitate communication" (Swaffar, J. K, 1985). Zyzik and Polio defined authentic materials as "those created for some real-life purpose other than language learning, and often, but not always provided by native speakers for native speakers" (Xan S, 2018). Nunan said authentic materials help students learn and use the foreign language more indicatively [8]. According to Richards, authentic materials are unprepared resources, such as texts, pictures, clips and etc., which are good as they provide information about the target language; they provide exposure to real language; they relate closely to learners' needs; they support a more creative approach to teaching (Richards. J.C, 2006).

We can assume that authentic materials are natural or "real life"; they are not intentionally written for teaching purposes. Their main objectives are to communicate meaning and information; in the language classroom they give refreshment from the textbook and expose language learners to a purposefully used language; more importantly, such materials give the opportunity to feel "in real life situations". However, it is crucial to adapt an authentic reading material in case of necessity to match the local context.

\section{Characteristics of good textbooks}

There are certain characteristics which must be taken into account while designing or selecting a textbook. If analyzed, all course books have elements of effective teaching materials to some extent.

Tomlinson characterizes good teaching materials as following: materials should achieve impact; materials should help learners to feel at ease; materials should help learners to develop confidence; learners should perceive learning materials as relevant and useful; materials should require and facilitate learner self-investment; learners must be ready to acquire the being taught; the learners' attention should be drawn to linguistic features of the input; materials should provide learners with opportunities to use the target language to achieve communicative purposes, through meaningful, realistic interaction; materials should consider the positive effects of instruction to be delayed, thus incurring recycling; materials should be attentive that learners differ in learning styles; materials should deliberate that learners differ in affective attitudes; materials should permit a silent period at the begging of instruction; materials should maximize learning potential by encouraging intellectual, aesthetic and emotional involvement which stimulates both right and left brain activities; materials should not rely too much on controlled practice; materials should provide opportunities for outcome feedback. (Tomlinson B, 2012).

Howard and Major highlight some principles for developing good teaching materials: English language teaching materials should be contextualized; materials should stimulate 
interaction and be generative in terms of language; English language teaching materials should encourage learners to develop learning skills and strategies; English language teaching materials should allow for a focus on form as well as function; English language teaching materials should offer opportunities for integrated language use; English language teaching materials should be authentic; English language teaching materials should link to each other to develop a progression of skills, understandings and language items; English language teaching materials should be attractive; English language teaching materials should have appropriate instructions; English language teaching materials should be flexible. (Howard, J. \& J. Major, 2004).

Cunningsworth emphasizes the importance of materials in language teaching as: a resource for presentation materials; a source of activities for learner practice and communicative interaction; a reference source for learner on grammar, vocabulary, pronunciation etc.; a source of stimulation and ideas for classroom activities; a syllabus; and a support for less experienced teachers lacking self-confidence. (Cunningsworth A, 1995).

Judging the given thoughts, good reading materials play a major role in organizing effective language learning environment by the teacher, as well as motivating the learner with its informative and engaging reading resources. As textbooks or other reading materials are important resources in language learning and teaching, their appropriateness and effectiveness deserve much attention. Thus, experts' suggestions should be taken a serious consideration by every material designer to achieve a desired goal.

\section{Necessity of culturally acceptable materials}

There are variety of language teaching and learning course books published in USA, UK and other countries. Undoubtedly, they meet the demands of many educators and language learners due to the fact they have effective tasks aimed at enhancing all four language skills. On the other hand, these books contain native culture enriched materials which are sometimes are unacceptable to none-native learners of English.

The necessity of culturally appropriate materials that are suitable to meet national standards can be felt enormously nowadays in many local contexts. This process involves centralized decision making by a government looking for a unified system of language instruction. For example, in Uzbekistan, according to national requirements text books are designed for secondary and secondary specialized education and they are used as a main resource all over the country. Let us first look at course books created for primary and secondary schools in Uzbekistan to see what opportunities they provide for learning.

"Kids' English" Pack (Xan S, 2018) has been created by the initiative of the Resolution \# 1875 of the President of the Republic of Uzbekistan on 10 December 2012 "About the measures on further development of foreign language teaching and learning system". It is intended for primary classes (1-4 classes) of English and consists of a Pupil's Book, Workbook, Multimedia DVD and Teacher's Book. The main objective of Kids' English is to help pupils develop the four Language Skills: listening, speaking, reading and writing. The authors of the book focused on teaching Modern English for Communication, thus special attention is paid to speaking and listening, which in the past have often been neglected. Young learners also create good foundation in Vocabulary, Grammar and Pronunciation so these are also developed systematically.

"Fly High" (Juraev L, 2005) is a series of books for secondary classes (5-9classes) of English. It provides materials that are arranged in a flexible way to cater for faster and slower classes. Fly High follows the State Educational Standards and syllabus for foreign languages that were developed and approved by the Scientific Methodical Council on Foreign Languages in February 2013. This pack of books aims to help 
pupils develop the four Language Skills similarly to Kids' English. Fly High encourages a learnercentered approach to teaching which is quite different from the ones used in the past. Another advantage of this book is that it contains many activities, exercises, debates, projects and games, which encourage pupils to use the new language naturally through working in pairs or in groups.

When selecting relevant reading materials for tertiary education for English as a Foreign Language (EFL) in Uzbekistan, teachers, as a rule, choose the resources given in the syllabus of the subject or suggested by experienced language teachers and experts. Suggested books for the first and second year students are "Skilful" set for reading and writing (Rogers L \& Wilkin J. 2017); "Academic Skills: Reading and Writing" (Zyzik, E. C., \& Polio, C, 2017); "Select Reading" (Lee, L \& Gundersen E, 2013); For experienced teachers, this freedom might be preferred, whereas novice teachers are sometimes troubled with their choices. In some cases, a group of teachers collaboratively search, evaluate, and select books for piloting or use as primary texts. All these books cater the needs of language teachers and learners, as the level is appropriate, the activities are meaningful, and the materials are helpful for the students to reach the desired objectives, however, the cost of these books is relatively high in comparison to local resources.

We assume that it is essential to commence designing authentic reading materials appropriate for students in Uzbekistan where most of the EFL students work with the texts given in welldesigned books like "Skillful", "Reading and Writing", "Select Reading" etc., that motivate language learners to learn foreign languages and their culture, with the colorful and meaningful tasks. It is commonly known, they promote interaction and most of the topics appear to be interesting for students. Moreover, they are created on the basis of CEFR guidelines and enable learners to enhance reading strategies.

\section{Challenges of using authentic materials}

There are a lot of theories that language teachers should be familiar with and take into consideration while teaching reading skills. One of the most common challenges shared by almost all the participants is materials are difficult to read, and learners struggle when asked to read in class. The difficulty can be caused by the lack of vocabulary knowledge that students have especially in the low-level English classes. Another reason is that these materials are beyond students' proficiency levels. Students have a sense of frustration among when working on the difficult text. In most cases, this feeling can lead students to give up reading. Judging this, text difficulty is one of the challenges of using authentic materials. Most of our students consider that some of the articles that are beyond their proficiency levels inhibit their motivation to read causing a sense of frustration. Other challenges that faced when reading daily newspapers, internet articles, scientific articles, blogs, instructions in class is the grammatical constructions and grammar rules which some students have not been introduced before. Below opinions of various authors about the challenges of authentic material have been reviewed.

According to Gilmore, careful planning, selection and sequencing of materials and tasks are recommended when using authentic materials (Krashen, S \& Terrell.T, 1983). He also summarizes challenges associated with using authentic materials:

- The cultural content may seem too unfamiliar.

- The content may become obsolete too quickly.

- The language may be too difficult.

- The vocabulary may be too specialized.

- The grammar structures may be too complex.

- The preparation may require too much time (Tomlinson. B, 1998).

Can these challenges be overcome effectively? In our teaching practice, we took the following steps to prepare reading materials for EFL university students. In accordance with the syllabus, firstly, selection of locally and culturally appropriate authentic material is vital. Next, it 
requires adaptation process so that the level of the text should match the level of proficiency of learners. When you are sure that the text is motivating, relevant and useful, you can work on the task design taking into account characteristics and learning styles of your audience of readers. Finally, you may ask an evaluative, constructive feedback from your learners as well as colleagues to make further improvements in the material design stage. All in all, the use of carefully selected authentic materials makes lessons fruitful for learners. Krashen and Terrell state that acquisition occurs when learners are able to comprehend challenging input and that comprehension is aided by clues related to the situation and context, among other factors. Their notions have implications for the EFL classroom: you need to make the input comprehensible but challenging, and the input should also be engaging, interesting, and relevant. In addition, you need to facilitate activities that promote a constant flow of comprehensible input and meaningful communication (Krashen, S \& Terrell.T, 1983).

Obviously, input plays important role in EFL classrooms, the use of locally relevant authentic materials enhances learners' proficiency. In our teaching practice, according to the PRESETT syllabus, it is recommended to focus on topics such as "Uzbekistan and the World",
"Work and Business", "Environment", "Relations", "Cross-cultural communication", "Mass Media", "Ethical Issues in Medicine, Science and Technology", "Education", "Social Issues" that are relevant to our local context; in addition, it is a nice idea to choose two reading materials where learners are engaged in developing analytical and critical thinking provoking tasks. One of these passages should be about your own country and the second one about a country which language your students are learning.

\section{Genres of written texts}

Chosing texts that contain aspects interesting for students and can be related to their social context, their feelings, or the world they have created makes reading effective for them. There are a number of different types or genres of written texts, the components of reading ability. Each genre of written text has its own set of governing rules and conventions. A reader must be able to anticipate those conventions to process meaning efficiently. With an extraordinary number of genres present in any literate culture, the reader's ability to process texts must be very sophisticated (Brown H. D, 1991). Brown divides text types into three commonly used genres. It is shown in the table below:

Table 1

\begin{tabular}{|l|l|l|}
\hline$\#$ & Genres & Text types \\
\hline 1. & Academic reading & General interest articles (in magazines, newspapers, etc.) \\
& & Technical reports (e.g., lab reports), professional journal \\
& & articles \\
& & Reference material (dictionaries, online encyclopedias, etc.) \\
& & Essays, papers \\
& & Test directions \\
\hline 2. & Job-related reading & Editorials and opinion writing \\
& & Messages (e.g., phone messages) \\
& Letters/e-mails \\
& Memos (e.g., interoffice) \\
& Reports (e.g., job evaluations, project reports) \\
& Schedules, labels, signs, announcements \\
\hline
\end{tabular}




\begin{tabular}{|l|l|l|}
\hline & & Forms, applications, questionnaires \\
& & Financial documents (bills, invoices, etc.) \\
& Directories (telephone, office, etc.) \\
& Manuals, directions \\
\hline 3. & Personal reading & Newspapers and magazines \\
& Letters, e-mails, greeting cards, invitations \\
& Messages, notes, lists, blogs \\
& Schedules (train, bus, plane, etc.) \\
& Recipes, menus, maps, calendars \\
& Advertisements (commercials, ads) \\
& Novels, short stories, jokes, drama, poetry \\
& Financial documents (e.g., checks, tax forms, loan \\
applications) & Forms, questionnaires, medical reports, immigration \\
& documents \\
& Comic strips, cartoons \\
\hline
\end{tabular}

Different genres of a text require different strategy to understand the content of the reading. If, for example, readers know that the text type is an instruction of medicine, they will expect information about the usage, dosage, directions and etc. All these genres can be sources of authentic materials for teachers to design reading tasks or choose appropriate reading materials.

\section{Reading strategies}

Aside from reading genres it is crucial to focus on reading strategies for comprehension of authentic reading materials. The following table shows the principal strategies for reading comprehension according to D. Brown ( Brown.H. D, 1991):

Table 2

\section{Identifying your purpose in reading a text}

2. Applying spelling rules and conventions for bottom -up decoding

3. Using lexical analysis (prefixes, roots, suffixes, etc.) to determine meaning

4. Guessing at meaning (of words, idioms, etc.) when you aren't certain

5. Skimming the text for the gist and for main ideas

6. Scanning the text for specific information (names, dates, key words)

7. Using silent reading techniques for rapid processing

8. Using marginal notes, outlines, charts, or semantic maps for understanding and retaining information

9. Distinguishing between literal and implied meanings

10. Using discourse markers (e.g., "in addition", "however," "nevertheless", etc.) to process relationships

\section{Prediction of suitability}

Reading activities should be meaningful enough to have students work on the language. According to Ausubel's theory people keep in their long-term memory aspects which are meaningful to them, but fail to remember at a certain point those which were not significant (Brown. H. D,1991). Thus, if we teach students skimming a text, but they do not know why this strategy is used, and the text is not interesting or 
not suitable for their age, gender, and level, students might not remember how to skim a text. Creating a meaningful context is essential for students to internalize the language, make learning easy and enjoyable.

After evaluation locally available course books for primary and secondary schools, and resources in use at tertiary education, we summarized the suitability of the reading text types for different levels of learners and reading strategies' development. Table 3 shows the developed reading strategy, genre and the appropriate level of the reading material.

Table 3 Results of the evaluation

\begin{tabular}{|c|c|c|c|c|}
\hline № & Source & $\begin{array}{c}\text { Developed Reading } \\
\text { Strategy }\end{array}$ & Genre & Level \\
\hline 1 & $\begin{array}{l}\text { Articles (in } \\
\text { magazines, } \\
\text { newspapers, etc.) }\end{array}$ & $\begin{array}{l}\text { 1)Scanning and skimming } \\
\text { 2)Extensive reading } 3 \text { ) } \\
\text { Reading between lines }\end{array}$ & Academic reading & $\mathrm{B} 1 ; \mathrm{B} 2 ; \mathrm{C} 1 ; \mathrm{C} 2$ \\
\hline 2 & $\begin{array}{lr}\text { Technical reports } \\
\text { (e.g., lab reports), } \\
\text { professional journal } \\
\text { articles }\end{array}$ & $\begin{array}{l}\text { 1)Making notes } \\
\text { 2)Analyzing the features } \\
\text { of the text } \\
\text { 3)Finding organizational } \\
\text { patterns }\end{array}$ & Academic reading & $\mathrm{B} 2 ; \mathrm{C} 1 ; \mathrm{C} 2$ \\
\hline 3 & $\begin{array}{l}\text { Reference material } \\
\text { (dictionaries, online } \\
\text { encyclopedias, etc.) }\end{array}$ & $\begin{array}{l}\text { 1)Use silent reading } \\
\text { techniques for rapid } \\
\text { processing; } \\
\text { 2)Using context to find } \\
\text { meaning }\end{array}$ & Academic reading & $\mathrm{A} 2 ; \mathrm{B} 1 ; \mathrm{B} 2 ; \mathrm{C} 1$ \\
\hline 4 & Test directions & $\begin{array}{l}\text { 1)Making judgments } \\
\text { 2) Finding signal words }\end{array}$ & & $\mathrm{A} 2 ; \mathrm{B} 1 ; \mathrm{B} 2 ; \mathrm{C} 1$ \\
\hline 5 & $\begin{array}{ll}\text { Editorials } & \text { and } \\
\text { opinion writing } & \end{array}$ & $\begin{array}{l}\text { 1)Use silent reading } \\
\text { techniques for rapid } \\
\text { processing } \\
\text { 2)Making notes } \\
\text { 3)Most/least important } \\
\text { ideas } \\
\text { 4)Drawing conclusions }\end{array}$ & Academic reading & $\mathrm{B} 1 ; \mathrm{B} 2 ; \mathrm{C} 1 ; \mathrm{C} 2$ \\
\hline 6 & $\begin{array}{l}\text { Messages (e.g., } \\
\text { phone messages) } \\
\text { Letters/e-mails } \\
\text { Memos } \\
\text { interoffice) }\end{array}$ & $\begin{array}{l}\text { 1)Scanning and skimming } \\
\text { 2)Analyzing the features } \\
\text { of the text } \\
\text { 3)Finding organizational } \\
\text { patterns }\end{array}$ & Job-related reading & $\mathrm{B} 1 ; \mathrm{B} 2 ; \mathrm{C} 1 ; \mathrm{C} 2$ \\
\hline 7 & $\begin{array}{l}\text { Reports (e.g., job } \\
\text { evaluations, project } \\
\text { reports) } \\
\text { Schedules, labels, } \\
\text { signs, } \\
\text { announcements }\end{array}$ & $\begin{array}{l}\text { 1)Making notes } \\
\text { 2)Scanning and skimming } \\
\text { 3)Using context to find } \\
\text { meaning }\end{array}$ & Job-related reading & $\mathrm{B} 1 ; \mathrm{B} 2 ; \mathrm{C} 1 ; \mathrm{C} 2$ \\
\hline
\end{tabular}




\begin{tabular}{|c|c|c|c|c|}
\hline 8 & Manuals, directions & $\begin{array}{l}\text { 1) Guess at meaning when } \\
\text { you aren't certain } \\
\text { 2) Scanning and } \\
\text { skimming } \\
\text { 3) Use silent reading } \\
\text { techniques for rapid } \\
\text { processing } \\
\text { 4)Making notes }\end{array}$ & Job-related reading & $\mathrm{B} 1 ; \mathrm{B} 2 ; \mathrm{C} 1 ; \mathrm{C} 2$ \\
\hline 9 & $\begin{array}{l}\text { Newspapers and } \\
\text { magazines }\end{array}$ & $\begin{array}{l}\text { 1)Analyzing the features } \\
\text { of the text } \\
\text { 2)Finding organizational } \\
\text { patterns } \\
\text { 3)Making notes }\end{array}$ & Personal reading & B1; B2; C1; C2 \\
\hline 10 & $\begin{array}{lr}\text { Letters, } & \text { e-mails, } \\
\text { greeting } & \text { cards, } \\
\text { invitations } & \end{array}$ & $\begin{array}{l}\text { 1)Most/least important } \\
\text { ideas } \\
\text { 2)Finding organizational } \\
\text { patterns }\end{array}$ & Personal reading & $\mathrm{B} 1 ; \mathrm{B} 2 ; \mathrm{C} 1 ; \mathrm{C} 2$ \\
\hline 11 & $\begin{array}{l}\text { Messages, notes, } \\
\text { lists, blogs }\end{array}$ & $\begin{array}{l}\text { 1)Extending vocabulary } \\
\text { 2)Scanning and skimming } \\
\text { 3)Making notes }\end{array}$ & Personal reading & $\mathrm{B} 1 ; \mathrm{B} 2 ; \mathrm{C} 1 ; \mathrm{C} 2$ \\
\hline 12 & $\begin{array}{l}\text { Schedules (train, bus, } \\
\text { plane, etc.) }\end{array}$ & $\begin{array}{l}\text { 1)Finding signal words } \\
\text { 2)Finding organizational } \\
\text { patterns } \\
\text { 3)Making notes }\end{array}$ & Personal reading & $\begin{array}{l}\mathrm{A} 2 ; \quad \mathrm{B} 1 ; \quad \mathrm{B} 2 ; \\
\mathrm{C} 1 ; \mathrm{C} 2\end{array}$ \\
\hline 13 & $\begin{array}{l}\text { Recipes, menus, } \\
\text { maps, calendars }\end{array}$ & $\begin{array}{l}\text { 1)Skimming and scanning } \\
\text { 2)Using context to find } \\
\text { meaning } \\
\text { 3)Making notes } \\
\text { 4)Drawing conclusions }\end{array}$ & Personal reading & $\begin{array}{l}\mathrm{A} 2 ; \quad \mathrm{B} 1 ; \mathrm{B} 2 ; \\
\mathrm{C} 1 ; \mathrm{C} 2\end{array}$ \\
\hline 14 & $\begin{array}{l}\text { Advertisements } \\
\text { (commercials, ads) }\end{array}$ & $\begin{array}{l}\text { 1)Most/least important } \\
\text { ideas } \\
\text { 2)Drawing conclusions }\end{array}$ & Personal reading & $\begin{array}{l}\mathrm{A} 2 ; \quad \mathrm{B} 1 ; \quad \mathrm{B} 2 ; \\
\mathrm{C} 1 ; \mathrm{C} 2\end{array}$ \\
\hline 15 & $\begin{array}{l}\text { Novels, short stories, } \\
\text { jokes, drama, poetry }\end{array}$ & $\begin{array}{l}\text { 1)Reading between the } \\
\text { lines to find meaning } \\
\text { 2)Most/least important } \\
\text { ideas } \\
\text { 3)Visualizing }\end{array}$ & Personal reading & $\begin{array}{l}\mathrm{A} 2 ; \quad \mathrm{B} 1 ; \quad \mathrm{B} 2 ; \\
\mathrm{C} 1 ; \mathrm{C} 2\end{array}$ \\
\hline 16 & $\begin{array}{l}\text { Financial documents } \\
\text { (e.g., checks, tax } \\
\text { forms, loan } \\
\text { applications) }\end{array}$ & $\begin{array}{l}\text { 1)Finding signal words } \\
\text { 2)Sorting ideas using } \\
\text { concept map } \\
\text { 3)Finding organizational } \\
\text { patterns }\end{array}$ & Personal reading & $\mathrm{B} 1 ; \mathrm{B} 2 ; \mathrm{C} 1 ; \mathrm{C} 2$ \\
\hline 17 & $\begin{array}{l}\text { Forms, } \\
\text { questionnaires, }\end{array}$ & $\begin{array}{l}\text { 1)Drawing conclusions } \\
\text { 2)Finding signal words }\end{array}$ & Personal reading & $\begin{array}{l}\mathrm{A} 2 ; \quad \mathrm{B} 1 ; \quad \mathrm{B} 2 ; \\
\mathrm{C} 1 ; \mathrm{C} 2\end{array}$ \\
\hline
\end{tabular}




\begin{tabular}{|l|l|l|l|l|}
\hline & $\begin{array}{l}\text { medical reports, } \\
\text { immigration } \\
\text { documents }\end{array}$ & & \\
\hline 18 & $\begin{array}{l}\text { Comic strips, } \\
\text { cartoons. }\end{array}$ & $\begin{array}{l}\text { 1)Visualizing } \\
\text { 2)Scanning and skimming } \\
\text { 3)Activating prior } \\
\text { knowledge } \\
\text { 4)Making inferences }\end{array}$ & Personal reading & $\begin{array}{l}\text { A1; A2; B1; } \\
\text { B2; C1; C2 }\end{array}$ \\
\hline
\end{tabular}

From the above table we inferred that reading different authentic texts should be selected taking into consideration learners' age, level, interest in reading genres and most importantly strategy development.

\section{RESULTS OF THE NEEDS ANALYSIS OBTAINED FROM THE INSTRUMENT APPLIED}

In order to choose the most appropriate reading materials for EFL students, we carried out a needs analysis survey to find out what students like and need to read in their target language. In this way, the material will be created considering students' real interests and needs. The instrument was applied to UzSWLU (Uzbekistan State University of World Languages) students who were taking reading courses required for their major. The students' ages range between 18 and 28 years, with 55 male and 195 female students for a total of 250 survey.

Figure 1. The graph represents the preference of reading genres by male and female EFL students

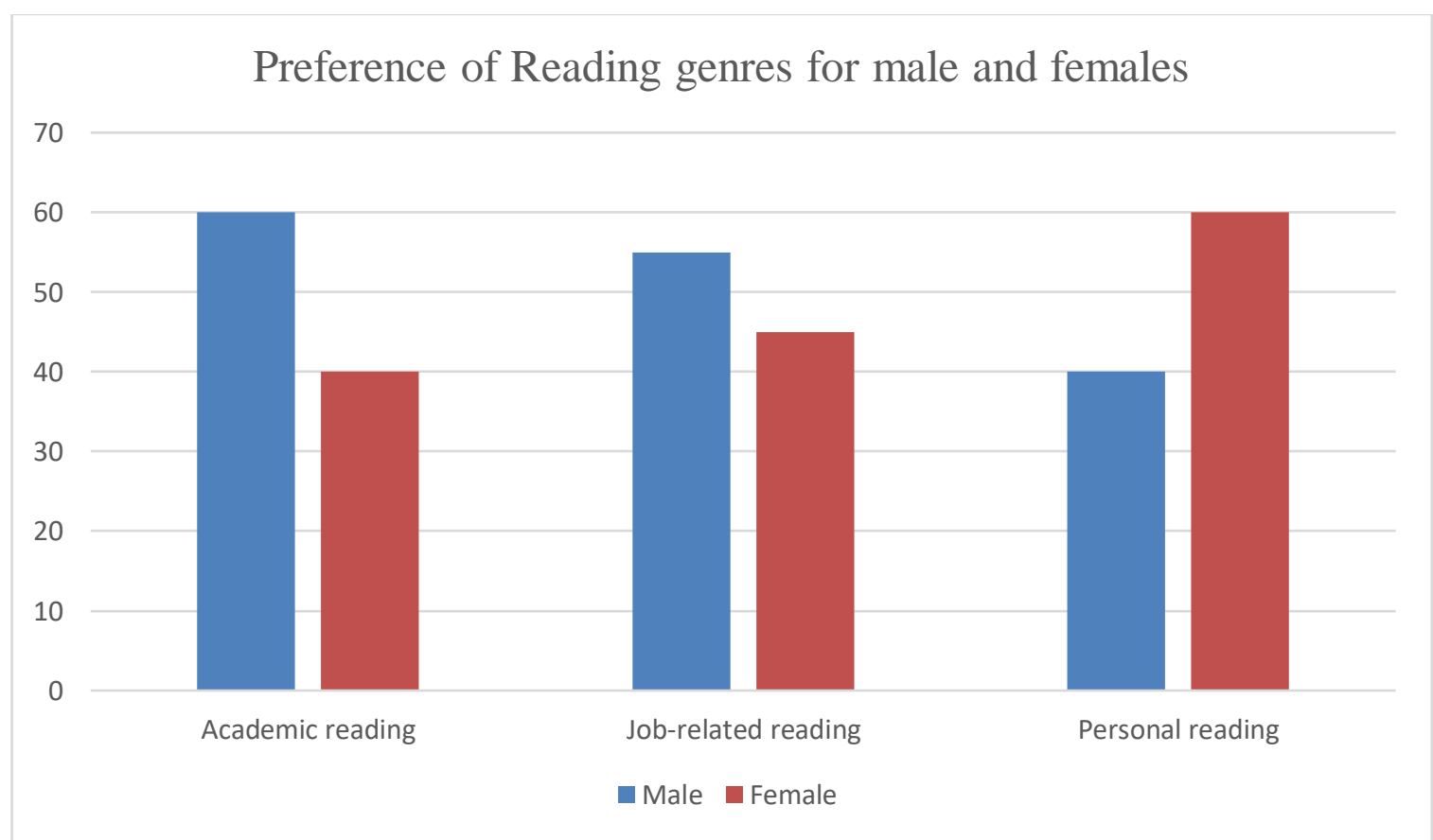

These results show that male students do like academic and job related reading genres rather than personal reading, however, female students are fond of personal reading genres.
In order to get more detailed information about learners' preferences, we analyzed each genre separately. We supposed this will help us to chose the most suitable text types where the most of the students belong to the same gender and 
similar tastes. The following graphs show the identify preferable types of texts in each genre. information collected from both genders to

Figure 2. The graph shows the results obtained from both females and males together. Texts of preference for males and females (Personal reading)

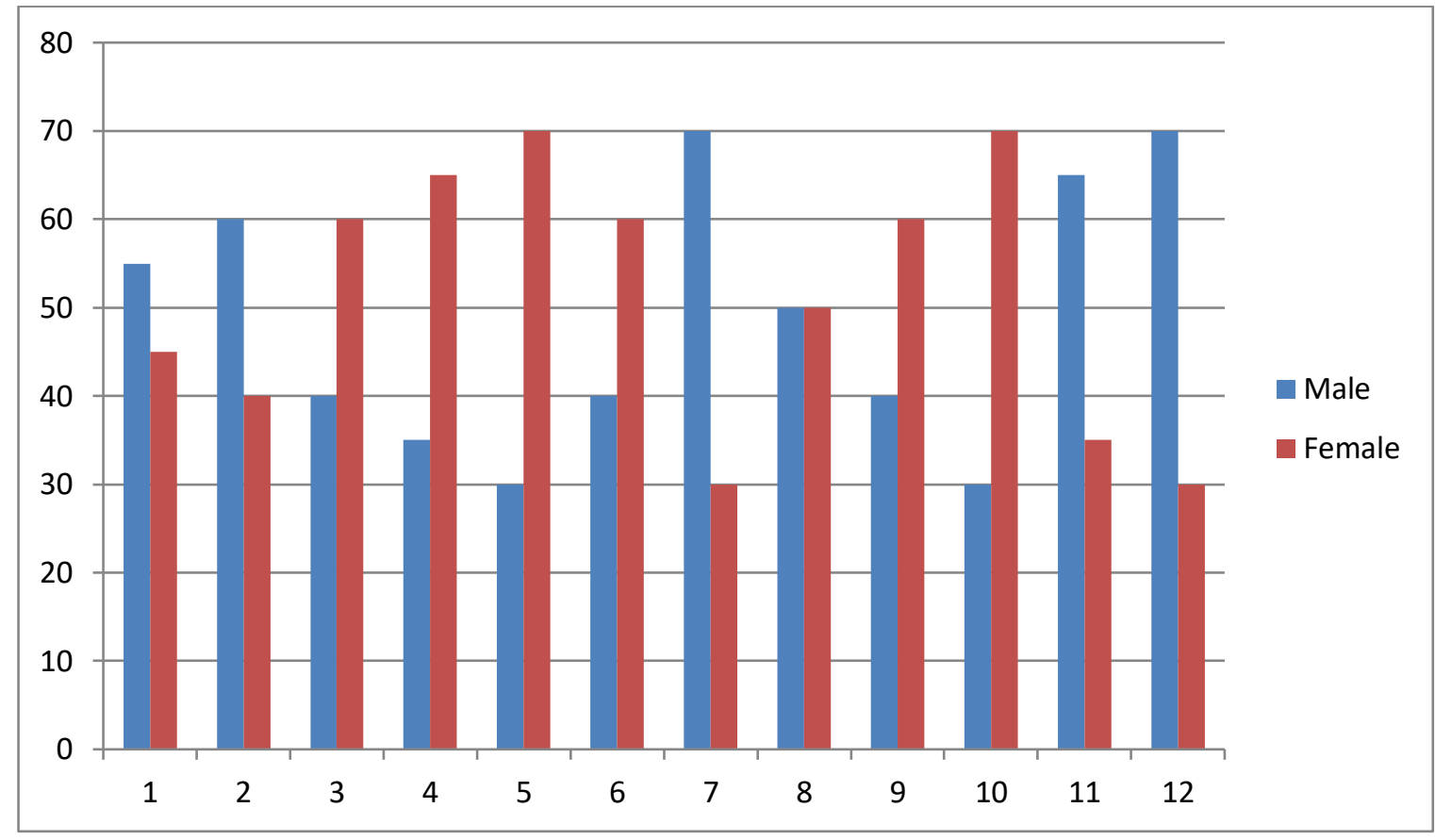

Types of texts: 1. newspapers and magazines.2.messages. 3. notes. 4.blogs. 5.recepies.6. menus.7.maps.8.advertisement.9.novels.10.short stories.11.jokes. 12.forms.

The graph presented above clearly show that male students' top favorites in terms of personal reading are maps, forms, jokes, newspaper and magazines, whereas, female students like to read recipes, short stories, blogs, notes, menus and novels.

Figure 3. The graph shows the results obtained from both females and males together.

Texts of preference for males and females (Academic reading) 


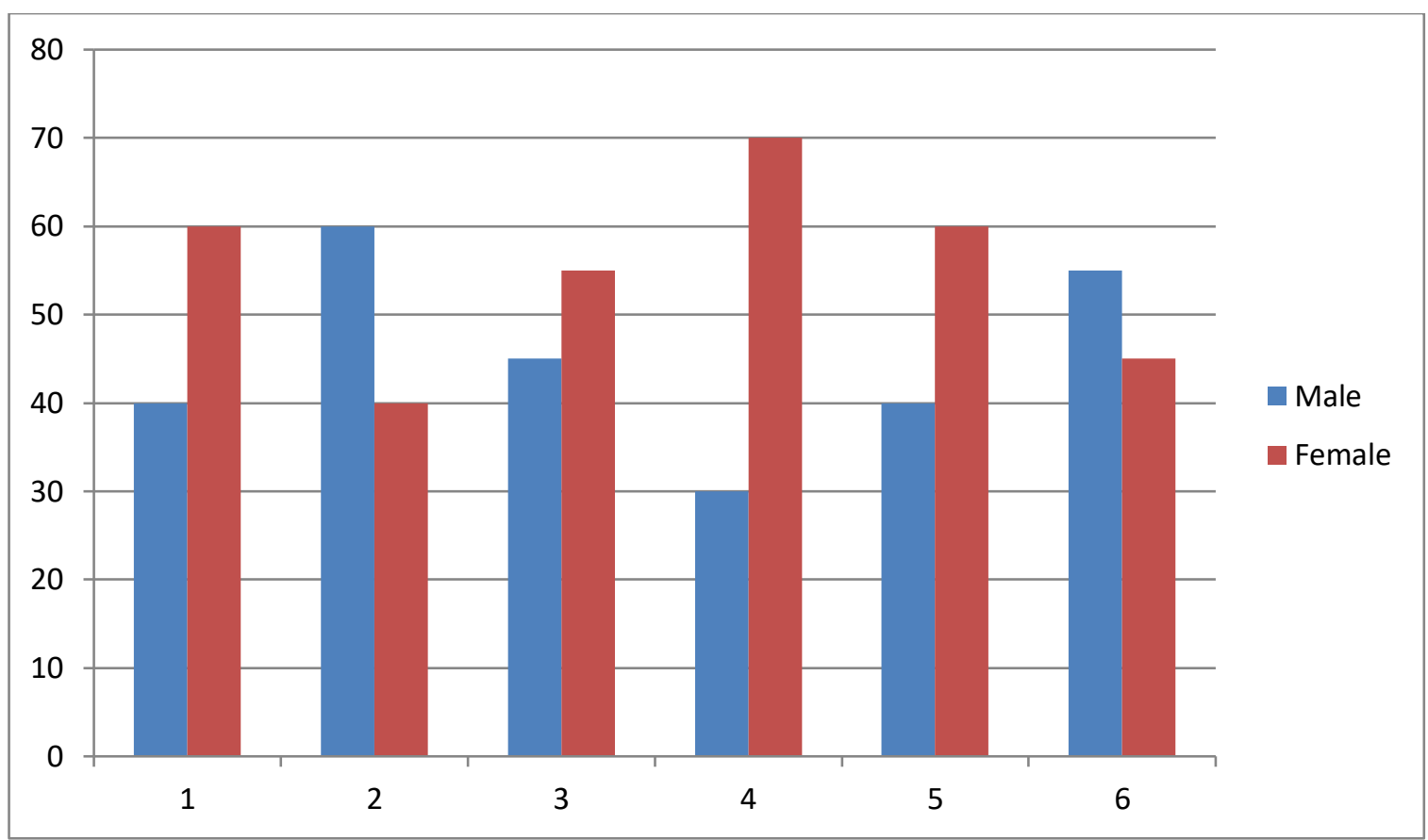

Types of texts: 1. general interest articles. 2.professional journal articles. 3.reference materials. 4.essays. 5.papers. 6.test directions.

The graph presented above clearly show that male students' top favorites in terms of academic reading are professional journal articles and general interest articles, whereas, female students like to read essays, papers and general interest articles.

Figure 4. The graph shows the results obtained from both females and males together. Texts of preference for males and females (Job-related reading)

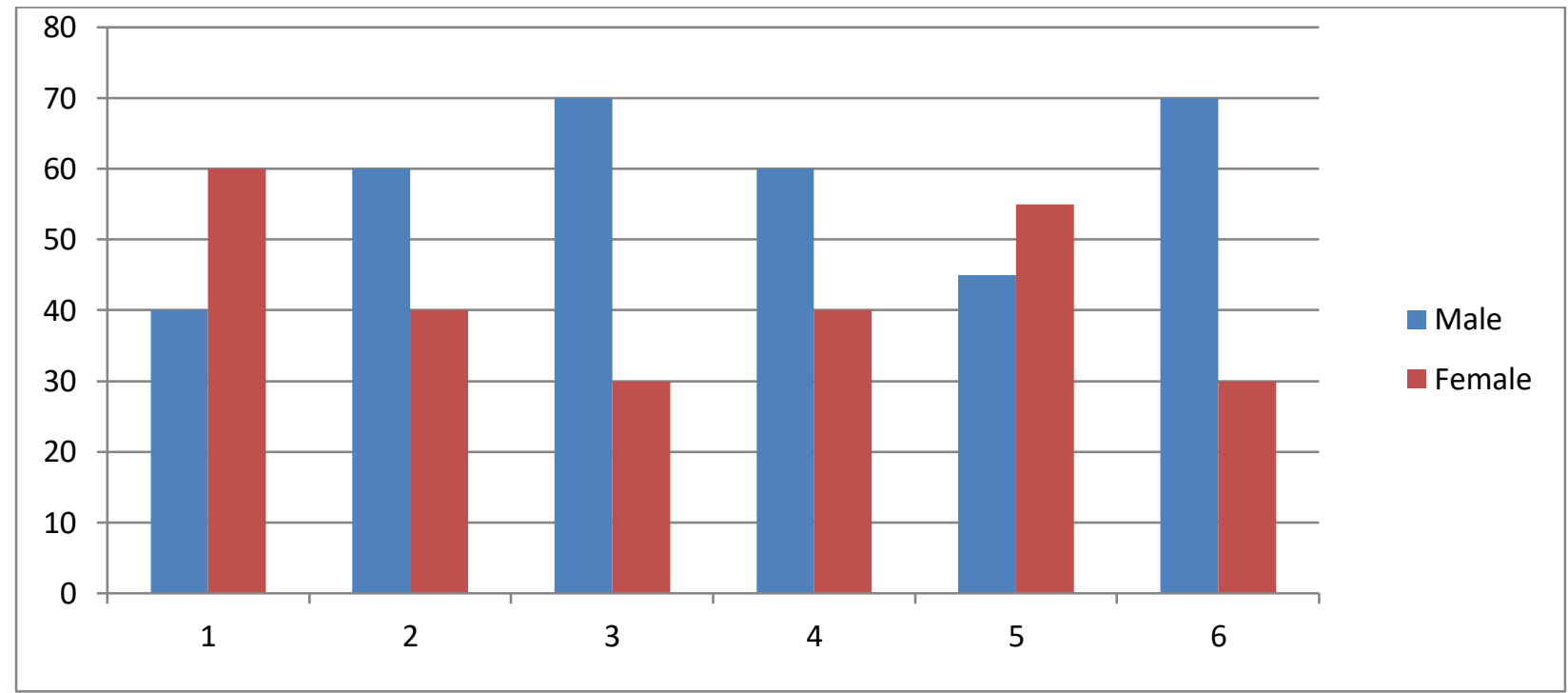

Types of texts: 1. Messages; 2.emails; 3.schedules; 4. announcements; 5. Manuals; 6. directions

This graph shows that schedules and directions are most favorite types of job-related reading for male students, whereas, emails, manuals are preferable ones for female students.

Figure 5. The graph shows the results obtained from both females and males together. 
After analyzing male and female students reading text types' preferences, we decided to get a clear picture of suggested text types of reading materials in the reading syllabus at Uzbekistan State University of World Languages. We included all the text types in the survey questions in order to know whether the students are receiving enough input reading their favorite text types, and feeling motivated.

\section{Texts EFL $1^{\text {st }}$ and $2^{\text {nd }}$ year students need to read}

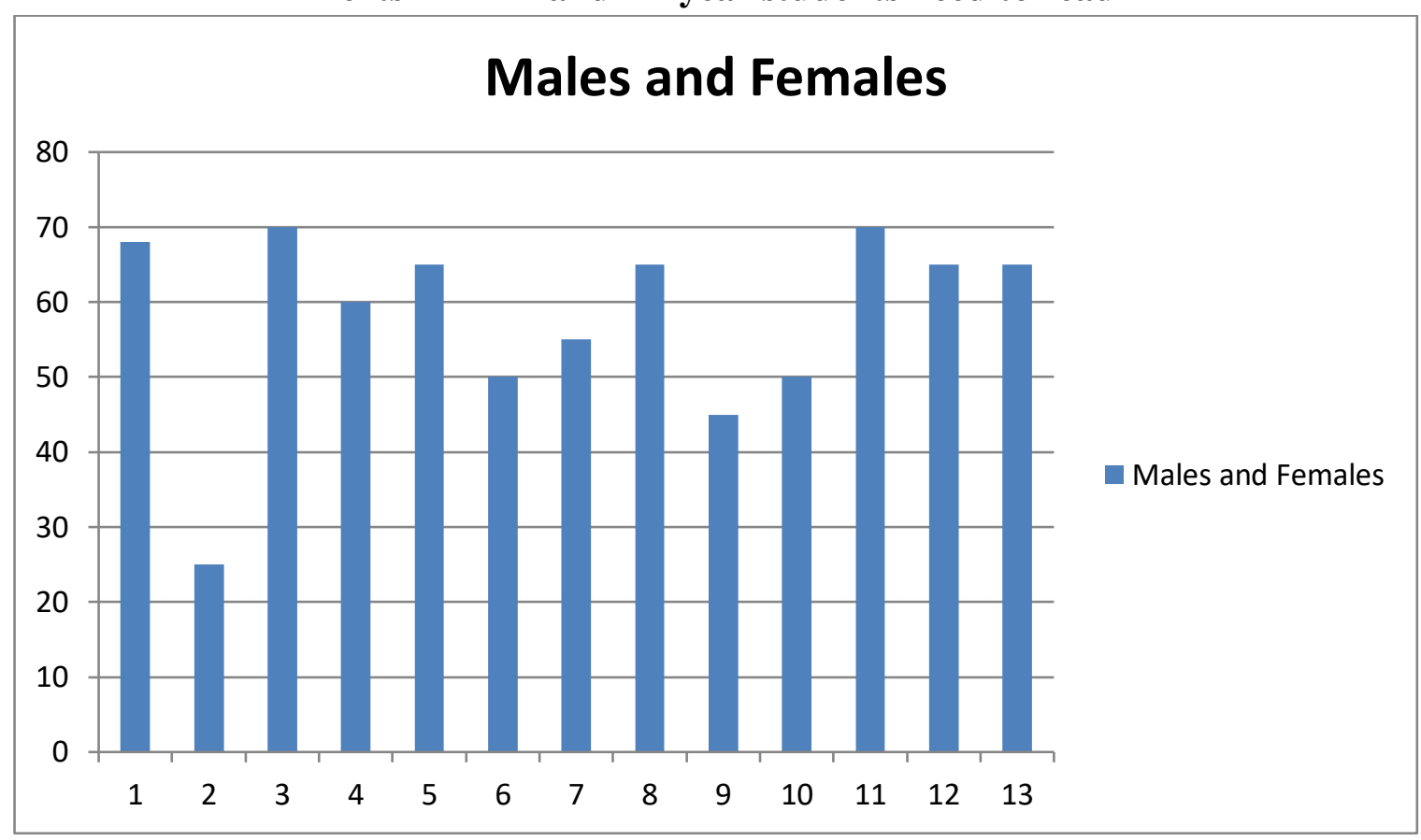

Types of texts: 1.newspapers and magazines; 2. recipes; 3.professional journal articles; 4. reference materials; 5.manuals; 6.directions; 7.short stories; 8. blogs; 9. schedules; 10. papers; 11.novels; 12. form; 13. notes.

These results suggest that students do like reading nearly all the text types included in the reading syllabus, particularly, articles in newspapers and magazines, professional journal articles, novels, various forms, notes, manuals, blogs and reference materials.

\section{CONCLUSION}

This study shows that authentic and culturally relevant materials play a vital role in teaching a foreign language. They can be very interesting and motivating to the language learners. Authentic materials contribute much to EFL teaching and learning when the materials are selected with sensitivity to the local context, and when they are used to communicate meaning and information. On this regard, we would like to highlight that in order to suit the proficiency level of students it is acceptable to adapt an authentic text, if needed. Preference of students is also very important in selection of reading materials. Carefully chosen authentic materials will increase learners' motivation and make learning process enjoyable as well. The strategies, genres discussed in this paper are just a few among many of the possibilities teachers can use as a basis for creating new tasks or adapting ready-made materials for use in their classroom. Undoubtedly authentic materials assist our students to become more active, and they can be used to improve overall language proficiency.

It is important to develop materials which are suitable for Uzbekistan students, where students get the opportunity to read "real life" texts and learn how to understand them. We must do our bests to find appropriate materials and teach our students focusing on their preferences and needs. We must work continuously to create 
useful materials and contribute much to the field of language learning and teaching in order to enhance the quality of education in our country.

\section{Acknowledgement}

We would like to express our gratitude to the stuff of Uzbekistan State World Languages University and the scientific advisor for giving us an opportunity to conduct our research there.

\section{REFERENCES}

[1] Brown, H. D. (1991). Language assessment: principles and classroom practices. New York: Pearson Education. P:243.

[2] Brown, H. D. (1994). Human Learning: Language Learning and Teaching. New Jersey: Prentice Hall Regents.p:228.

[3] Cunningsworth, A. (1995). Choosing your Coursebook.London: Macmillan.

[4] Howard, J. \& J. Major. (2004). Guidelines for designing effective English language teaching materials. Retrieved from http://www.paaljapan.org/resources /proceedings /PAAL9/pdf/

[5] Juraev L., and others. (2005) Fly High. Tashkent: Oqituvchi.

[6] Krashen, S., and T. Terrell. (1983). The natural approach: Language acquisition in the classroom. Harward, CA: Alemany.

[7] Lee, L., and Gundersen E. (2013) Select reading. Intermediate. Oxford University Press.

[8] Nunan, D. (1991). Language teaching methodology: A textbook for teachers. Edinburgh, Harlow, England: Longman. $250 \mathrm{p}$.

[9] Richards, J.C. (2006). Communicative Language Teaching Today. Cambridge: Cambridge University Press. Pp:20-21.

[10] Rogers L., and Wilkin J. (2017) Skillful. Macmillan Academic Skills. 110 p.

[11] Swaffar, J. K. (1985). Reading authentic texts in aforeign language: A cognitive model. The Modern Language Journal 69 (1).pp:15-34.

[12] Tomlinson, B. (2012). Materials Development for Language Learning and Teaching. Cambridge: Cambridge University Press.pp:143-179.

[13] Tomlinson, B. (1998). Materials Development in Language Teaching. Cambridge: Cambridge University Press.p.45.

[14] Widdoson, H.G. (1978). Teaching Language as Communication. Oxford: Oxford University Press.

[15] Xan, S., and others. (2018) Kids English.Tashkent:Oqituvchi.

[16] Zyzik, E. C., \& Polio, C. (2017). Authentic materials myths: Applying second language research to classroom teaching. Michigan, MI: University of Michigan Press. Retrieved from https://doi.org/10.3998/mpub.7892433

[17] ZemachD., and Rumisek L. (2003). Academic writing. Macmillan Education press. 